\title{
The Relation Between Organizational Health and Organizational Commitment
}

\author{
Asst. Prof. Dr. Aydan Yüceler \\ Necmettin Erbakan University, Faculty of Health Sciences, Konya, Turkey \\ email: aydanyuceler@hotmail..com

\section{Dr. Burcu Doğanalp} \\ Selcuk University, Faculty of Economics and Administrative Sciences, Konya, Turkey \\ email: burcusbf@yahoo.com \\ Asst. Prof. Dr. Ş. Didem Kaya \\ Necmettin Erbakan University, Faculty of Health Sciences, Konya, Turkey \\ email: dkaya@konya.edu.tr
}

Doi:10.5901/mjss.2013.v4n10p781

\begin{abstract}
Modern management understanding considers human resources to be one of the most important assets of the organizations. While a successful organization will care to choose this asset from among the most qualified candidates, it should also endeavor not to lose its existing employees. In the literature, organizational commitment expresses both the employees' continuing to stay in the organization and their serving more willingly with the sense of belonging they feel to the organization they work in. The studies on how the concept of organization health, which is a holistic review of the concepts of employee welfare and organizational effectiveness, are very few in the literature. In this context, the matter of how organizational commitment, a critical variable for the organizations, is affected by organization health was examined in our study.
\end{abstract}

Keywords: Organizational Commitment, Organization Health

\section{Introduction}

Today, along with the influence of the globalization and increase of the competition, the perception of employee in the enterprises has differentiated. In this context, the enterprises adopt their employees as internal customers, and strive to eliminate the factors that could affect their efficiencies and quality of their business lives negatively. In doing this, the two aspects aimed at are the organizations' not wishing to lose the qualified employees they have, and enabling the employees exhibit fully their knowledge, experiences and talents they have.

The topic of organization health and organizational commitment, the two concepts which the organizations can draw from to achieve these aims, constitute the main subject matter of this study. In this context, revealing effect of the organization health on the organizational commitment will demonstrate the importance of organization health for the enterprises.

Accordance with this understanding, we aim to explain the relationship these two concepts in question which are extremely important in terms of management with our work.

\section{The Concept of Organization Health and Organizational Commitment}

Many studies have been conducted on organization health and organizational commitment, and these two concepts have often been addressed separately. But this study sought to analyzed both concepts together.

\subsection{The Concept of Organization Health}

In the business management literature, the concepts such as organization culture, organizational stress, organizational commitment, business ethics and business satisfaction, etc. were concentrated on, but the necessary importance was 
not attached to the concept of "organization health". This prevented the concept of organization health from being a known and recognized concept. Despite all these, when reviewed the concept of organization health, it is seen to incorporate all the concepts mentioned above and to provide a more holistic perspective (Lyden\&Klingele, 2000: 3).

Although the concept of organization health was first used by Argyris in the 1950s (Tutar, 2010: 184), its foundations go back to the 1960s, when the specialists of human relations and behavioral sciences who strived to produce a solution to the question of how the employees should be treated (Gül, 2007: 321).

Accordingly, the concept of organizational health, first put forward in 1969 by Matthew Miles, is a simulation developed on the climate of schools (Miles, 1969: 376). The relations between the students, teachers and managers in school were defined by this simulation(Polatcl et al., 2008: 147).

The researchers attribute use of this concept in school to two reasons. The first is that school is regarded as a social system in which the managers, teachers and students take part. Thus, organization health should reflect the social interaction between these key representatives. The second is that organization health is necessary for healthy schools for the purpose of efficiency in performance of certain functions. While it is though that the concept of organization health cannot be used in other organizations due to these two reasons, it can be suggested that they may be applicable for other organization structures, too. Thus, this approach of Miles was adopted also in the field of organizational behavior, and was as an introduction to the studies in this topic (Köseoğlu\&Karayormuk, 2009: 176-177).

In this context, Miles suggested a model for organization health analysis of schools, and defined the healthy organization as follows. "Healthy organization is one that does not survive only in the environment it exists, but also constantly develops in the long term, improves its coping and surviving skills." (Miles, 1969: 378).

However, like many other management concepts, the concept of organization culture does not have a clear definition agreed on. Many researchers exhibited their own approaches in terms of both its definition and determination of its dimensions.

In general, organization health is expressed as the capabilities possessed by an organization to adapt to its environment successfully, create cooperation between its members and achieve its targets (Altun, 2001: 5). In more particular, organizational health, addressed as a concept that studies the employee welfare and organization effectiveness together (Ardıç ve Polatcı, 2007: 140). According to another approach, organization health is defined in connection with the health and wellbeing of the employee (Köseoğlu\&Karayormuk, 2009: 177).

According to another definition; it is such an organization that supports organizational success, environment, employees' welfare and happiness with its authority structure, values system, norms, reward and sanction systems (Karagüzel, 2012: 4).

When looked at the definitions about organization health, it can be suggested that there is a focusing from the general to the private in the historical process. In other words, this concept that was suggested as a metaphor to assess general performance of an enterprise offers new insights by putting the employee health and welfare to the forefront. In this context, the literature on organization health can be suggested to have developed with three different approaches focused on enterprise performance, on employee health, and on both enterprise performance and employee heath (Köseoğlu\&Karayormuk, 2009: 177).

\subsubsection{Dimensions of Organization Health}

Since 1965, "organization health" has drawn the attention of particularly Matthew B. Miles and Wayne K. Hoy, and based on the researches, they have defined this concept, stressed its importance, and then developed dimensions to be able to measure the organization health, which they argued to be important for the organization success (Polatcı et al., 2008: 147).

\subsubsection{The Organization Health Dimensions Developed by Miles}

According to the model brought forward by Miles, dimensions of the organization health may be summarized as follows (Hoy\&Feldman, 1987: 30, Buluç, 2008: 576-578, Karagüzel, 2012: 9-10).

- The Task Needs Dimension

1. Objective-Focus: The objectives are easily understandable, acceptable and achievable by the organization members.

2. Communication Adequacy: An in-organization communication system preventing misunderstandings is available. Thus, the employees access correct information and increase organization efficiency. 
3. Optimal Power Uniformity: Distribution of the power within the organization is relatively uniform. They always think that those at lower levels can influence those at the immediate upper level.

- Survival Needs Dimension

4. Effective Use of Resources: Task distribution within the organization is done in the most effective way neither less nor more than as required. There is a coherence between the demands and needs.

5. Organizational Commitment: The employees like the organization and want to stay there. They are influenced by the organization, and spend all their powers for unity of the organization.

6. Morale: There is employee welfare and team satisfaction in the organization in general.

- Growth and Development Needs Dimension

7. Innovativeness: The organization develops new procedures, sets new targets and constantly develops.

8. Autonomy: It is proactive to the organization. It shows several independent characteristics to the outer factors.

9. Adaptation: The organization has the skill of making the necessary changes in itself for growth and development.

10. Problem Solving Competency: The problems are solved with minimum energy. Problem solving mechanism is constantly supported and strengthened.

\subsubsection{Organization Health Dimensions Developed by Hoy}

Hoy and Feldman examined organization health in seven dimensions. These seven dimensions are as follows (Hoy\&Feldman, 1987: 32, Buluç, 2008: 576-578, Karagüzel, 2012: 9-10):

1. Organizational Integrity: The organization's ensuring an integrity in its programs through its capability of adaptation to its environment.

2. Influence of the Organization Manager: The organization managers can influence decisions of the senior system they are subordinate to. The ability to convince their decision organs, having reputation and not being blocked by the hierarchic impediments are important factors of the organization managers.

3. Respect: This involves the friendly, supportive, overtly and sincerely behaviors exhibited by the organization managers to the employees. Such behaviors are important for increase of performances of the employees.

4. Work Order: This involves behaviors of the organization manager relating to his/her tasks and achievements. Expectations from the employees, performance standards and polices are clearly expressed by the organization manager.

5. Resource Support: This involves availability of sufficient machinery and equipment in the organizations, and procurement of additional resources when requested.

6. Morale: This is the sum of friendship, openness between the organization members, and the senses of excite and confidence they feel about the work they do. The employees treat each other tolerantly, they help each other, feel proud of the organization they work in, and completing the works make them happy.

7. Importance of the work: This is about the organizations' seeking for work excellence. Work is started by setting high but achievable targets for the employees, and production activities are carried out in a serious and orderly fashion.

It is possible to group these dimensions as organization health dimensions at the institutional, managerial and technical level. Accordingly, Institutional Level consists of institutional integrity dimension, Managerial Level consists of the dimensions of work order, respect, influence of the organization manager and resource support, and Technical Level consists of the levels of morale and importance of the work (Polatcl et al., 2008: 149).

\subsubsection{Organization Health Dimensions Developed by World Health Organization}

With a more general classification in regard to the dimensions of organization health, the World Health Organization (WHO) examines the organization health in 4 dimensions. These are as follows (Cooper\&Williams, 1994: 8, Ardıç\&Polatcı, 2007: 146):

1. Environmental Health: This involves the work area factors such as physical environment of the workplace, noise, heat, light, dangerous substances and machinery.

2. Physical Health: This involves the physical health of the employees in the organization, illness, injury, and activities such as medicine treatment. 
3. Psychological Health: This involves self-confidence of the employees, their stress, depression, anxiety states, and behavioral styles.

4. Social Health: This involves friendships in the workplace, social support, workplace relations, and factors outside business.

According to the World Health Organization, there are not precise lines between these factors, and there are connections among these four dimensions. According to this perspective, only physical and spiritual health of the employees is addressed, and the managerial and organizational output dimensions are not included (Altun, 2001: 44).

\subsubsection{Measuring Organization Health}

People usually do not know the value of their health and pay the necessary attention to their health until they get sick. Likewise, in the organization management, methods of doing business, policies and practices are not paid attention to until a warning is received. Managers usually do not measure organization health until they encounter a crisis. However, in order to achieve and sustain organizational health, a healthy organization structure should be formed beginning from establishment of the organization, measures should be taken against the problems that may occur, and organization health should be measured periodically (Ardıç\&Polatcı, 2007: 138).

The aim of measuring health of the organizations is not only to reveal the situation, but also to prepare improvement plans based on the obtained results. The organization's being healthy or unhealthy is an evidence for need of change and innovation. The essential thing is determining what causes the unhealthy organization structure. Briefly, measurements set the conceptual basics in identification and solution of the problems. The strengths and weaknesses of the organization as well as the opportunities and threats it has are revealed through measurement of organization health. Thus, it is strived to derive more resources from the strengths, and to improve and strengthen the weaknesses (Polatcl et al., 2008: 146).

\subsubsection{Characteristics of Healthy and Unhealthy Organizations}

It is required to know the characteristics of healthy and unhealthy organization so as to derive the desired benefit from organizational health. In the light of these characteristics, the organization should be analyzed, the revealed data should be interpreted, and solution of the problems leading to the unhealthy structure should be ensured (Polatcı et al., 2008: 149).

Table 1: Characteristics of Healthy and Unhealthy Organizations

\begin{tabular}{|c|c|}
\hline Healthy Organizations & Unhealthy Organizations \\
\hline Open to innovation and improvement & Not open to innovation and improvement \\
\hline Its long term effectiveness is high & Its long term effectiveness is low \\
\hline Employees are ensured to participate in the decisions & Employees apply the decisions made by top management \\
\hline Organizational commitment is developed & Organizational commitment is not developed \\
\hline Responsible to the environment and employees & Not responsible to the environment and employees \\
\hline Proactive, takes preventive measures & Reactive, corrective actions are taken \\
\hline Work stress is low & Work stress is high \\
\hline Work satisfaction and workplace peace is high & Work satisfaction and workplace peace is low \\
\hline Importance is attached to employees & Importance is not attached to employees \\
\hline Number of absences and quits is little & Number of absences and quits is big \\
\hline Communication between the individuals and top management is strong & Communication between the individuals and top management is weak \\
\hline Worker safety is present, work accidents are scarcely encountered & Worker safety is not present, work accidents are frequently encountered \\
\hline Employees work with high motivation and exhibit high performance & Employees work with low motivation and exhibit low performance \\
\hline $\begin{array}{l}\text { Unfavorable internal and external environmental conditions cannot } \\
\text { damage the organization }\end{array}$ & $\begin{array}{l}\text { Unfavorable internal and external environmental conditions can damage } \\
\text { the organization }\end{array}$ \\
\hline Team spirit is developed, employees act with the sense of "us" & $\begin{array}{l}\text { Team spirit is not developed, employees act towards their personal } \\
\text { interests }\end{array}$ \\
\hline Employees feel themselves safe in the organization & Employees do not feel themselves safe in the organization \\
\hline Information flow is robust and timely & Robust and timely information flow is unavailable \\
\hline Strategies are put into practice successfully & Incapable to put strategies into practice \\
\hline An open, trust-focused and encouraging organization culture is present & A closed, retributive and unfair organization culture is present \\
\hline Problems are intervened by digging into their causes & $\begin{array}{l}\text { Evidences of the problem are addressed, the core cause cannot be } \\
\text { identified }\end{array}$ \\
\hline The organization is efficient and effective & The organization is not efficient and effective \\
\hline
\end{tabular}

Source: Karagüzel, 2012: 21 
In conclusion, characteristics of healthy organizations may be briefly listed as follows (Cicchelli, 1975):

- Objectives and responsibilities are clearly set,

- Systematic problem solving and evaluation is performed,

- A constructive and open-to-change organization spirit is present,

- The energy required for growth and development and the feedback system are available.

\subsubsection{What to do to enhance Organization Health}

As in the human organism, healthy structure is hereditary in most of the organizations (Aguire et al., 2005:1). However, a study revealed that each organization can use specific methods and tools to enhance organization health. Several arrangements are required for changing the organization structure and being able to form a healthy organization structure (Vasie and Lucas, 2001: 481).

According to Miles, the following five approaches are very important for increasing the organization health (Miles, 1969: 376):

- Supporting personal development

- Placing importance on communication

- Strengthening information flow

- Establishing an open-to-change organization culture

- Specialist support

\subsection{The Concept of Organizational Commitment}

Increase of attention of the different disciplines such as organizational behavior, organizational psychology and social psychology to the topic of organizational commitment, and bringing by the researchers from these fields their own perspectives to the topic make it difficult to understand the concept of organizational commitment. In this respect, Morrow states that more than twenty five different definitions about organizational commitment are present in the literature (Gül, 2003: 74). Although there is a consensus upon the fact that commitment to the organization is a direct relationship between the employee and the organization, there are dissents about structure and formation of this relationship. This dissent is reflected on the definition of the concept of organizational commitment, and results in emergence of different definitions. Some definitions concerning organizational commitment are given below (Meyer\&Herscovitch, 2001: 302; Ince\&Gül, 2005: 3; Balay, 2000: 14-16; Illsev, 1997: 5; Bildiren, 2001: 38; Karaca, 2001: 48; www.insankaynaklari.com, www.isguc.org);

- One of the first definitions in the topic of organizational commitment was made by Grusky in 1966. According the said author, organizational commitment is the "strength of bond of the individual to the organization".

- As a result of the study conducted in 1979 by Mowdey, Steers and Porter, they defined the organizational commitment as an affective bond between the employee and the enterprise. According to them, organizational commitment is the relative strength of the individual's identification with and participation in a given organization.

- According to Meyer and Allen, organizational commitment expresses the psychological approach of the employee to the organization, and is a psychological state reflecting the relationship between the employee and the organization, leading to the decision of continuing the organization membership.

- According to Rietzer and Trice, it is a psychological phenomenon based on the level of meaningfulness of the organization according to the individual.

- According to Hall, Schneider and Nygren, it is the process where the organization and the individual to integrate and become coherent over time.

- According to Buchanan, organizational commitment is a whole consisting of the elements of identification with the organization, adopting the work and loyalty to the organization. Apart from the objectives and values of the organization, role of the individual determined on the basis of these objectives and values and the interestbased value, it is commitment to the organization itself in a partisan and emotional manner.

- It is the strength of the individual's identification with the organization and participation in the organization. In other words, organizational commitment is the strength of the individuals' identifying himself/herself with and being nested within the organization. Identification with the organization involves the dimension of loyalty that 
incorporates sharing the objectives with other organization members, the sense of belonging to the organization, and supporting the objectives and policies of the organization.

In the light of the definitions above, organizational commitment may, in general, be summarized as phenomenon characterized with three factors. The said factors may be listed as (Steers\&Porter, 1983: 443, Yalçın\&ijplik, 2005: 397, www.insankaynaklari.com, Önal, 1999: 9; Çetin, 2004:90);

- Accepting and believing in the objectives and values of the organization,

- Willing to strive for benefit of the organization and continuous development, and finally,

- Being enthusiastic to remain as part of the organizational structure.

An organization having employees with high organizational commitment implies that it has a strong organizational structure. This results in increase of will of being part of this culture for the new starting employees and the responsibility of fulfilling organizational expectations. When this is achieved, the employees accept, adopt the organizational culture, and make it part of their values. Organizational culture affects the organizational commitment by serving as a bridge for the employees between their priorities and the organization's objectives. It supports formation or reinforcement of the organizational commitment by ensuring development of a sense of identity and encouraging participation in the organizational objectives among the employees (Gül, 2003: 75).

\subsubsection{Organizational Commitment Classifications}

While the initial studies on organizational commitment describe organizational commitment as a one-dimensional structure reflecting internalization of the organizational values, Meyer and Allen revealed that organizational commitment had three different elements (Coleman et al., 1999: 996). The said elements which are affective, continuance and normative commitment can be explained as follows (İnce\&Gül, 2005: 39):

- Affective Commitment: Affective commitment of the employee to the organization reflects integration with the organization. Affective commitment can be suggested to involve acceptance by the employees of the organizational objectives and values, and their making extreme effort for the benefit of the organization (Gül, 2002: 45).

Individuals with a high affective commitment stay in the organization "because they want to", and are desirous to make great effort for the interests of the organization. Hence, it is the type of commitment which is most desired to take place in the organizations and desired to be instilled to the employees (Uyguç\&Çımrın, 2004: 91).

- Continuance Commitment: In the literature, this type of commitment is also referred to as rational commitment and perceived cost. Continuance commitment means being aware of the costs to be entailed by quitting the organizations.

- In continuance commitment, the senses are thought to play a very little role in commitment to the organization. Continuance commitment is the sense of continuing the organization membership since it is thought that cost of quitting the organization would be high (ilsev, 1997: 22).

- Normative Commitment: In 1990, Meyer and Allen developed the three dimensional organizational commitment model by adding the dimensions "normative" or "ethical" as suggested by Weiner and Vardi and developed by Weiner to the affective and continuance commitment.

Normative commitment shows faith of the employees concerning the responsibility felt by them to their organizations. As normative commitment has developed as a result of the employee's perceiving his/her showing commitment to his/her organization as a duty and social responsibility and thinking that commitment to the organization is right, it represents a dimension that is different from the other two types of commitment (Gül, 2002: 45).

Normative or ethical commitment differs from affective commitment in that the individual regards working in the organization as a duty for himself/herself and feels that showing commitment to the organization is "right", and from the continuance commitment in that it not affected by calculation of the losses to result from quitting the organization (Solmuş, 2004: 215).

The common point between all the three types of commitment is existence of a bond between the individual and the organization that reduces the likelihood of quitting the organization. Namely, in all these three types of commitment, the employees continue to stay in the organization. However, in the first, the motive of staying in the organization is based on willingness, in the second, on necessity, and in the third, on obligation (Balay, 2000: 72). 


\subsubsection{Factors Influencing Organizational Commitment and Their Consequences}

Feeling commitment to the organization by the employees brings favorable results for the organization by increasing their work efficiencies. Hence, an organization's being aware of the factors that can increase or reduce commitment of the employees to the organization confronts us as in important factor (Balay, 2000; Çetin, 2004: 99). This is clearly shown in the following figure.

Figure 1. Factors Influencing Organizational Commitment and Their Consequences

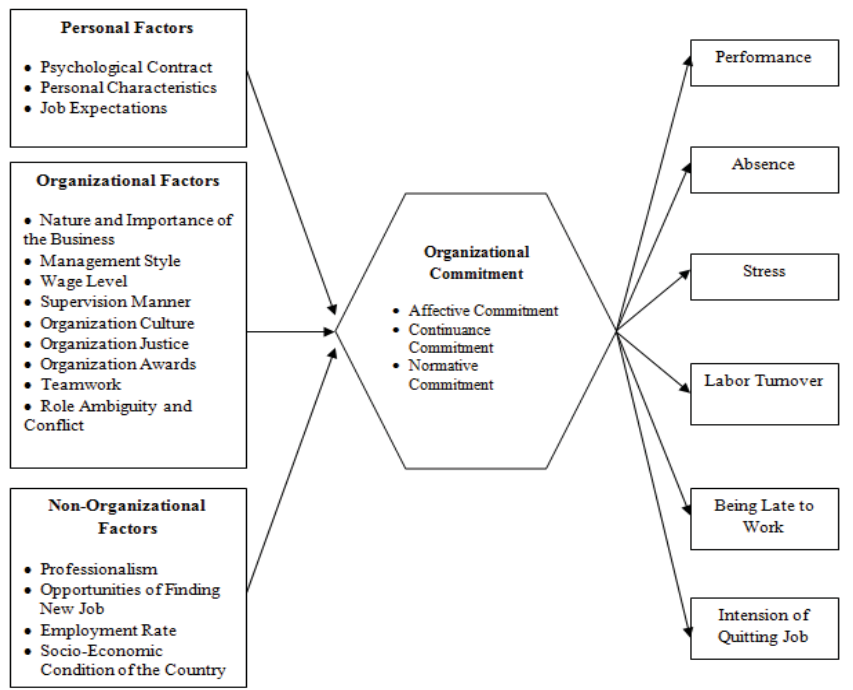

Source: Adapted from Suliman, 2002: 170.

\section{Conclusion}

In an environment where competition is increasingly exacerbating, it has become highly important for the organization managements to manage the employees' attitudes and behaviors regarding work in a proper and healthy manner. Many researches setting out from this point express that a coherent climate in the organization is an important factor of advantage for the organizations to acquire the competition advantage. Formation of the said organization climate will increase commitment of the employees to the organization. Emergence of a desired organization climate can only be achieved by formation of a healthy organization structure. In this context, organization health promises to the organization management commitment of the employees to the organization and performance increase of the employees by creating a desired working environment.

Organization health must be enhanced in order to retain the human resources, which are an extremely important value for the employers. The managers should make efforts towards enhancing organization health of the enterprises to increase commitment of the employees and keeping the personnel turnover rate low. Formation of such organizations which have ensured coherence with their environment, have effective managers, where employees are respected, roles have been clearly set, access to the necessary resources is easy, employees have high morale, and success is valued, will ensure that the employees have a favorable organizational commitment that is created through the employees' genuine desires and adoption of the organization's targets.

Moreover, forming and developing the organizational health reduces the organization costs while positively influencing many factors such as organization effectiveness, work satisfaction, organizational commitment, organizational performance and employee health. It can be suggested that, since, by this way, both effectiveness and efficiency increases, and the costs incurred as result of the activities decrease, healthy organizations have competition advantage compared to unhealthy organizations.

In conclusion, although the necessary importance has not been attached to the concept of organization health to date, organization health is more important than ever particularly in today's business life, and confronts us as a topic that 
needs to be investigated. A healthy organization structure must be established at the individual and organizational level for an effective organization structure.

\section{References}

Aguire, D. M., L. W. Howell, D. B. Kletter ve G. L. Neilson (2005), A Global Check- Up: Diagnosing The Health of Today's Organizations, Organizational DNA Research Report.

Altun, Saadet Akbaba (2001), Örgüt Sağıı̆ı, 1. Basım, Ankara: Nobel Yayın Dağııım.

Ardiç, Kadir, Sema Polatçı (2007), İşgören Refahı Ve Örgütsel Etkinlik Kavramlarına Bütüncül Bir Bakış: Örgüt Sağlığı, Atatürk Üniversitesi Iktisadi Ve İdari Bilimler Dergisi, 21(1).

Balay, Refik (2000). Yönetici ve Öğretmenlerde Örgütsel Bağlııı. Ankara: Nobel Yayınları.

Bildiren, Mustafa (2001). Çalışanların Güçlendirmenin Örgütsel Bağlılı̆a Etkisi ve Bir Uygulama. Yüksek Lisans Tezi, Gebze İleri Teknoloji Enstitüsü, Sosyal Bilimler Enstitüsü. Gebze.

Buluç, Bekir (2008), Ortaöğretim Okullarında Örgütsel Sağlık Ile Örgütsel Vatandaşlık Davranışları Arasındaki Illişki, Türk Eğitim Bilimleri Dergisi, $6(4)$.

Cicchelli, Jerry J. (1975), Assessing the Organizational Health of School Systems, Annual Convention of The American Association of School Administrators.

Coleman Daniel F., Gregory P. Irving, Christine L. Cooper (1999). Another Look At The Locus Of Control- Organizational Commitment Relationship: It Depends On The Form Of Commitment. Journal Of Organizational Behavior 20; 1999.

Çetin, Münevver Ölçüm (2004). Örgüt Kültürü ve Örgütsel Bağlılık. Ankara: Nobel Yayınları.

Çöl, Güner (Ocak 2005). Örgütsel Bağılık Kavramı ve Benzer Kavramlarla Illişkisi. İnsan Kaynakları Dergisi; Cilt:6 Sayı:2; 2004; www.isguc.org/arc_view.php?ex=233; 10.01.2005.

Gül, Hasan (2002). Örgütsel Bağlılık Yaklaşımlarının Mukayesesi Ve Değerlendirmesi. Ege Akademik Bakış Dergisi, Cilt:2 Sayı:1.

Gül, Hasan (2003). Davranışsal Bağılık Yaklaşımı Ve Değerlendirmesi; Celal Bayar Üniversitesi Yönetim ve Ekonomi Dergisi; Cilt:10 Sayı:1; Manisa.

Gül, Hasan (2007), İ̧ Stresi, Örgütsel Sağlık ve Performans Arasındaki Illişkiler: Bir Alan araştırması, Karamanoğlu Mehmetbey Üniversitesi Sosyal ve Ekonomik Araştırmalar Dergisi, 9(13).

Hoy, W. K., ve Feldman, J. A. (1987), Organizational Health: The Concept and Its Measure, Journal of Research and Development in Education, 20, Summer.

İlsev, Arzu (1997). Örgütsel Bağlılık: Hizmet Sektöründe Bir Araştırma. Yüksek Lisans Tezi, Hacettepe Üniversitesi Sosyal Bilimler Enstitüsü. Ankara.

İnançlar, Tutumlar Ve İş Ahlakı : İş Tatmini Ve Örgütsel Bağlılık Üzerindeki Etkisi (Temmuz 2003) www.insankaynaklari.com/cn /ContentBody.asp?BodyID=564; 30.07.2003.

Ince, Mehmet, Hasan, Gül (2005). Yönetimde Yeni Bir Paradigma: Örgütsel Bağlılık. Konya: Çizgi Kitapevi.

Karaca, Samuray (2001). İş Tatmininin Örgütsel Bağlılık Üzerindeki Etkisi ve Bir Uygulama. Yüksek Lisans Tezi, Pamukkale Üniversitesi Sosyal Bilimler Enstitüsü. Denizli.

Karagüzel, Ensar Selman (2012), Örgüt Sağlığının Örgütsel Bağlıığa Etkisinin İncelenmesi (Bir Devlet Üniversitesi Örneği), , Yüksek Lisans Tezi, Sakarya Üniversitesi Sosyal Bilimler Enstitüsü. Sakarya.

Kömürcüoğlu, Hüseyin (Ocak 2005). Belirsizlik Ortamında İş Tatmini ve İşe Bağılık. Innsan Kaynakları Dergisi; Cilt:5 Sayı:1; 2003; www.isguc.org/arc view.php?ex=36; 10.01.2005.

Köseoğlu, Mehmet Ali ve Kemal Karayormuk (2009), Örgüt Sağlığı Nedir: Yöneticiler Arasında Görüş Farklıı̆ı Var mıdır?, Atatürk Üniversitesi IïBF Dergisi, 23(2).

Lyden, J. A. ve W. E. Klingele (2000), Supervising Organizational Health, Super Vision, 61(12).

Meyer John P., Lynne Herscovitch (2001). Commitment In The Work Place Toward A General Model. Human Resource Management Review 11.

Miles, M. B. (1969), Planned Change and Organizational Health: Figure and Ground, in F. D. Carver \& T. J. Sergiovanni (Eds.) Organizations and Human Behavior: Focus on Schools, New York, McGraw Hill.

Miller, R. E., Mark, A. G. \& Peter, M. H. (1999), Personality and Organizational Health: The Role of Conscientiousness, Work \&Stress, 13(1).

Önal, Kevser (1999). Çalışanın Kuruma Bağlıı̆̆ı: Bir Özel Hastane Uygulaması. Yüksek Lisans Tezi. Gazi Üniversitesi Sosyal Bilimler Enstitüsü İşletme Anabilim Dalı Hastane İşletmeciliği Y.Lisans Programı. Ankara.

Polatci, Sema, Kadir Ardıç, Adem Kaya (2008), Akademik Kurumlarda Örgüt Sağlığı ve Örgüt Sağlığını Etkileyen Değişkenlerin Analizi, Celal Bayar Üniversitesi, Yönetim ve Ekonomi Dergisi, 15(2).

Solmuş, Tarık (2004). İ̧̧ Yaşamında Duygular ve Kişiler Arası Ilişkiler. İstanbul: Beta Yayınevi.

Steers, Richard M., Lyman W. Porter (1983). Motivation and Work Behavior. McGRAW-HILL Book Company.

Suliman, A. M. T. (2002). Is it Really a Mediating Construct? The Mediating Role of Organizational Commitment in Work Climate-Performance Relationship; Journal of Management Development, Sayı:21 Cilt:3.

Tutar, Hasan (2010), İşgören Yabancılaşması Ve Örgütsel Sağlık Illişkisi: Bankacılık Sektöründe Bir Uygulama, Ankara Üniversitesi Siyasal Bilgiler Fakültesi Dergisi; Sayı:1 Cilt: 65.

Uyguç, Nermin, Dilek, Çımrın (2004). Deü Araştırma Ve Uygulama Hastanesi Merkez Laboratuarı Çalışanlarının Örgüte Bağıııklarını Ve İşten Ayrılma Niyetlerini Etkileyen Faktörler; 1. Dokuz Eylül Üniversitesi I.I..B.F.Dergisi; Cilt:19 Sayı:1; İzmir.

Vasie, L. H. ve W. R. Lucas (2001), An Assessment of Health and Safety Management within Working Groups in the UK Manufacturing Sector, Journal of Safety Research, 32.

Yalçin, Azmi, Fatma Nur İplik (2005). Beş Yıldızlı Otellerde Çalışanların Demografik Özellikleri İle Örgütsel Bağlılıları Arasındaki İlişkiyi Belirlemeye Yönelik Bir Araştırma: Adana İli Örneği; Çukurova Üniversitesi Sosyal Bilimler Enstitüsü Dergisi; Cilt:14 Sayı:1. 